\title{
Effects of Melatonin on Primary Oral Wound Healing in Rats
}

\author{
Saja M. Mohammed ${ }^{1}$, Mohammed S. Sulaiman ${ }^{1}$ and Ghada A. Taqa ${ }^{2}$ \\ ${ }^{1}$ Department of Oral Surgery, College of Dentistry, University of Mosul, Mosul, Iraq. \\ 2 Department of Dental Basic Science, College of Dentistry, University of Mosul, Mosul, Iraq. \\ *Corresponding Author: Saja M. Mohammed, E-Mail: saja.dep5@ student.uomosul.edu.iq
}

\begin{abstract}
This study aimed to investigate the effects of melatonin on primary wound healing of the oral mucosa in rats. Thirty healthy male albino rats were used in this study, almost at the same weight, age, and circumstance. All animals were submitted to operation in the buccal mucosal region. Each animal was given a mixture of xylazine and Ketamine hydrochloride Intraperitoneal (I.P.). After about 5 minutes, anesthetic integrity was checked by testing rats' reflexes. After complete anesthesia, each animal was laid down on the dorsal recumbency, via intraoral approach, a full-thickness soft tissue incision $0.5 \mathrm{~cm}$ length in the right buccal mucosa. The incision was closed by a single simple interrupted stitch using a 5/0 silk suture to heal by primary intention. The animals were randomly divided into two main groups: control group $(n=15)$ and melatonin $(\mathrm{n}=15)$ group, which receives melatonin $(10 \mathrm{mg} / \mathrm{kg} / \mathrm{daily})$ solution orally, then each main group were subdivided into three subgroups (each group 5 rats ) according to the time of sacrifice $3^{\text {rd }}, 7^{\text {th }}$ and $9^{\text {th }}$ days after surgery respectively. Biopsies were taken from the site of operation and examined by three histopathologists. The statistical analysis showed significant differences in the inflammatory response between the melatonin-treated and control group at all periods of healing. There were significant differences in granulation tissue formation between the melatonin-treated and control groups at the $7^{\text {th }}$ and $9^{\text {th }}$ day healing times. Also, a significant difference existed in reepithelialization between the melatonin-treated and control groups at the $9^{\text {th }}$ day periods of healing. This study concluded that the melatonin appeared good healing accelerator of oral soft tissue healing in rats .
\end{abstract}

Original Article:

DOI:https://dx.doi.org/10.21608/javs.2 021.98771.1108

Received :29 September, 2021. Accepted :20 November, 2021. Published in January, 2022.

This is an open access article under the term of the Creative Commons Attribution 4.0 (CC-BY) International License . To view a copy of this license, visit:

http://creativecommons.org/licenses/by/4.0/

J. Appl. Vet. Sci., 7(1 ): 24-30.

Keywords: Buccal mucosa, Melatonin, Rats, wound healing.

\section{INTRODUCTION}

The oral mucosa, a specialized moist tissue lining the oral cavity, extends from the skin mucosal junction (vermillion border) of the lips anteriority to the oropharynx posteriorly (Bahadur, 2021). the oral mucosa plays a critical role as a barrier against exogenous substances, pathogens, and mechanical stresses (Liu et al., 2010).

The wound is defined as primarily damaged or disruption of skin/mucosa contributed to the loss of its microstructure stability and undergoes a complex wound healing process (Salleh and Fauzi, 2021). The primary goals of wound management are rapid wound closure, a functional and aesthetically satisfactory scar (Kujath and Michelsen, 2008). According to the physiology of wound healing, wounds can be divided into two types: acute and chronic (Martin and Nunan,
2015). Wound healing can also be divided into three categories, depending on the mechanism and timing of closure: primary intention, secondary intention, and tertiary intention (Prasetyono, 2009). Overall, wound healing is accomplished through three overlapping but distinct biological processes: (hemostasis), inflammation, proliferation, and remodeling (Almadani et al., 2021).

The use of natural products and antioxidants substances, such as melatonin, has attracted a great deal of attention (Ozler et al., 2010). Melatonin (N-acetyl5-methoxytryptamine) is an endogenous neurohormone with well-reported anti-inflammatory and antioxidant properties (García-Bernal et al., 2021); melatonin was discovered and isolated from bovine pineal in 1958 by Turkish scientist Aaron Lerner (Lerner et al., 1958). melatonin is a natural methoxyindole first described as a pineal hormone and later present in most 
mammalian and non-mammalian cells (Pandi et al., 2017). Exogenous melatonin's present in dietary meats such as chicken, lamb, beef, pork but also in fish, eggs, and colostrum, melatonin regulates a variety of physiological functions, such as circadian rhythm and circadian clock genes, reproduction, modulation of mood, sexual behavior or the immune system, and regulation of body temperature and blood pressure (Anadón et al., 2021).

Melatonin exerts antioxidant, immunomodulatory, pro-apoptotic, antiproliferative, and antiangiogenic effects (Najafi $\boldsymbol{e t}$ al., 2019). Therapeutic effects of melatonin have been reported in several disorders such as certain tumors, cardiovascular diseases, or psychiatric disorders. Indeed, oncostatin effects of melatonin have been reported in several tumors (breast cancer, ovarian and endometrial carcinoma, human uveal melanoma, prostate cancer, hepatomas, and intestinal tumors) (Gurunathan et al., 2021). Many research shows that endogenously produced and exogenously-applied melatonin is beneficial to the oral cavity in several conditions such as periodontitis, mucositis, cancers. Furthermore, melatonin has been observed to enhance osseointegration and bone regeneration (Najeeb et al., 2016). So, this study aimed to investigate the effects of melatonin on primary wound healing of the oral mucosa in rats.

\section{MATERIALS AND METHODS}

\section{Modeling Experiment:}

This research will include thirty healthy male albino rats of similar age (3 months) and weight (250$300 \mathrm{gm}$ ). Rats were chosen from animal maintenance situated in the Veterinary Medicine/University of Mosul (Iraq). Plastic cages were used to keep the animals with a 12-hours light 12 hours dark period at a temperature $\left(22 \pm 3^{\circ} \mathrm{C}\right)$ and access to the daily diet and tap water ad-libitum. This research was carried out following international veterinary science protocols on the use of animals. All measurements were taken with the permission of the Mosul University ethical committee to avoid animal cruelty.

\section{Medication:}

Melatonin (Green Field Nutrition, USA) solution was prepared by mixing $(10 \mathrm{mg} / \mathrm{kg})$ of melatonin powder with $(1 \mathrm{ml})$ of normal saline with continuous mixing until a homogenous solution was formed (Dos et al., 2020).

\section{Experimental Groups and Procedures:}

All rats received a mixture of general anesthesia ketamine hydrochloride $(100 \mathrm{mg} / \mathrm{kg})$ and xylazine $(8 \mathrm{mg} / \mathrm{kg})$ as a sedative, analgesic, and muscle relaxant drug intraperitoneally (Heng et al., 2020). Complete anesthesia was obtained within 5 minutes; this kept the animal anesthetized for about 50 minutes.Then each animal was laid down on the dorsal side on the surgical board, via intraoral approach, a full-thickness soft tissue incision $0.5 \mathrm{~cm}$ length in the right buccal mucosa then the incision was closed by a single simple interrupted stitch using (5/0) silk suture to heal by primary intention (Tang et al., 2015). After the surgical procedure had been completed then randomly selected animals were divided into two main experimental groups as the following:

- Control group $(n=15)$ : no treatment was received.

- Melatonin group $(\mathrm{n}=15)$ : which received melatonin $(10 \mathrm{mg} / \mathrm{kg} /$ daily) solution orally.

Then Each main group subdivided according to the time of sacrifice as a following:(Tas et al.,2015)

G1: Three days after surgery, the animals were sacrificed.

G2: Seven days after surgery, the animals were sacrificed.

G3: Nine days after surgery, the animals were sacrificed.

\section{Histological Observation:}

Oral mucosa specimens were preserved in $10 \%$ neutral buffer formalin solution then washed with distal water to remove the excess of formalin. After that, it was processed with ethanol and xylol, then embedded and marked in paraffin wax blocks and lastly freeze for 24 hours. These blocks were sliced into slices using a microtome; each slice is between 4-5 $\mu \mathrm{m}$ in thick and stained with Hematoxylin and eosin stain (H\&E), then examined under a light microscope (Canciani et al., 2021).

\section{Criteria of histopathological examination:}

1.Criteria of inflammatory response parameter (scoring):

- Score 1: Nil No inflammatory cells seen in the field of operation.

- Score 2: Mild When inflammatory cells present in few numbers, less than $1 / 2$ of the field.

- Score 3: Moderate Inflammatory cells could be seen in more than $1 / 2$ of the field.

- Score 4: Severe or abundant when inflammatory cells present in huge numbers, more than $3 / 4$ of the field.

2. Criteria for the amount of granulation tissue formation (Scoring) (Sultana et al., 2009; Gupta and Kumar, 2015).

- Score 1: Absent of granulation tissue formation in the wound.

- Score 2: Quantity of granulation tissue formation in the wound gap is scanty.

- Score 3: Amount of granulation tissue formation is moderate in tissues. 
- Score 4: Total amount of granulation tissue formation in the wound is profound.

3. Criteria of re-epithelization parameters (Scoring) (Al-Saffar et al., 2020)

- Score 0: Reepithelialization at the edge of the wound.

- Score 1: Reepithelialization covering less than half of the wound.

- Score 2: Reepithelialization covering more than half of the wound.

- Score 3: Reepithelialization covering the entire wound, irregular thickness.

- Score 4: Reepithelialization covering the entire wound, normal thickness.

\section{Statistical Analysis:}

The data were expressed as mean \pm standard deviation (S.D.), the variation between two experimental sets was statistically evaluated using the Mann-Whitney U test. Statistical significance was accepted for ( $\mathrm{p}$-value $\leq * 0.05)$.

\section{RESULTS}

On day 3 of an induced wound, the mean value of inflammatory cells $(3.8 \pm 0.44)$ in the control group is the highest, while the mean value of inflammatory cells $(2.8 \pm 0.44)$ in melatonin groups and the mean value of granulation tissue is $(1.6 \pm 0.54)$, and the mean value of reepithelialization $(0.2 \pm 0.44)$ of control group while the mean value of granulation tissue $(2.4 \pm 0.98)$, and the mean value of reepithelialization $(0.4 \pm 0.89)$ which is the highest value of melatonin group. The p-value of inflammation was found to be less than 0.05 , indicating that the two groups are significantly different. Still, there is no significant difference between the two groups in granulation tissue formation and reepithelialization ( Figs. $1 \& 2$ ).

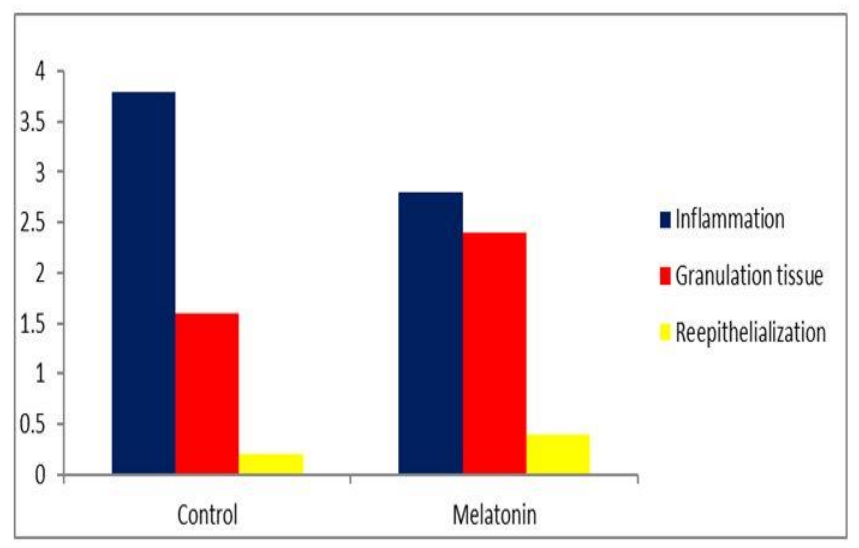

Fig. 1: Mean rank differences between variables treated systemically on the $3^{\text {rd }}$ day of oral mucosa wound healing for inflammation, granulation tissue formation, and reepithelialization.
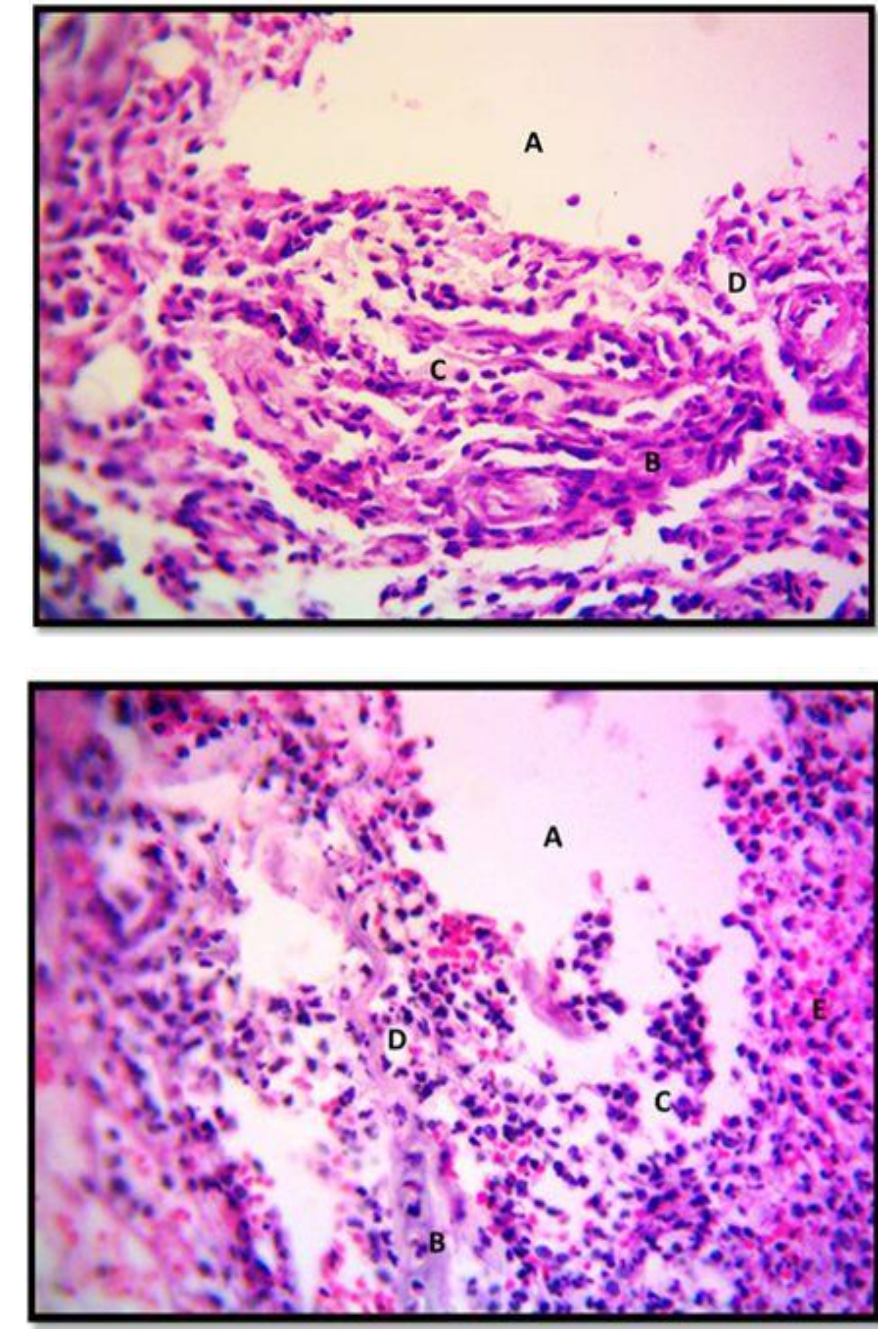

Fig. 2: Photomicrograph of third day period oral mucosal wound of I. Control group and II. Melatonin group (A) shows the site of the wound, (B) represents granulation tissue, (C) inflammatory infiltration, (D) peripherally presents new blood vessels (angiogenesis), and it is without reepithelialization. H\&E stain, 400X for both.

Post-wounding on day seven, the group treated with melatonin remained the lowest in inflammatory cells infiltration and the highest in granulation tissue and reepithelialization wound healing score. The mean value of inflammatory cells infiltration $(3.4 \pm 0.54)$ of the control group and the mean value of granulation tissue $(2.2 \pm 0.44)$ and reepithelialization $(0.8 \pm 0.83)$, while the mean value of inflammatory cells infiltrates (2.2 \pm 0.44$)$, granulation tissue $(3.4 \pm 0.54)$, and reepithelialization $(1.8 \pm 0.44)$ of melatonin group. A *p-value of the wound scores was discovered to be $\leq 0.05$ that indicates a significant variation between the two groups in inflammation and granulation tissue formation, while the (p-value ) of reepithelialization was found to be more than 0.05 which indicates no significant difference between the two groups ( Figs. 3 \& 4 ). 
Saja M. Mohammed et al......

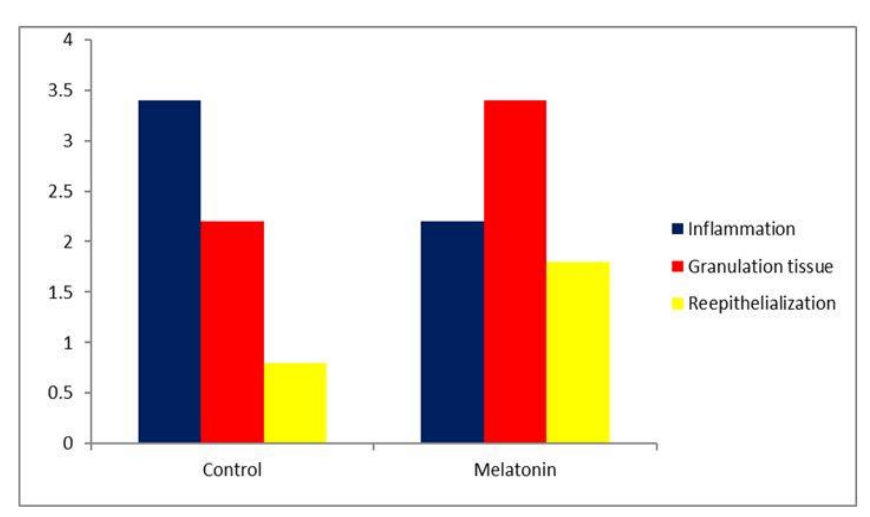

Fig. 3: Mean rank differences between variables treated systemically on the 7th day of oral mucosa wound healing for inflammation, granulation tissue formation, and reepithelialization.

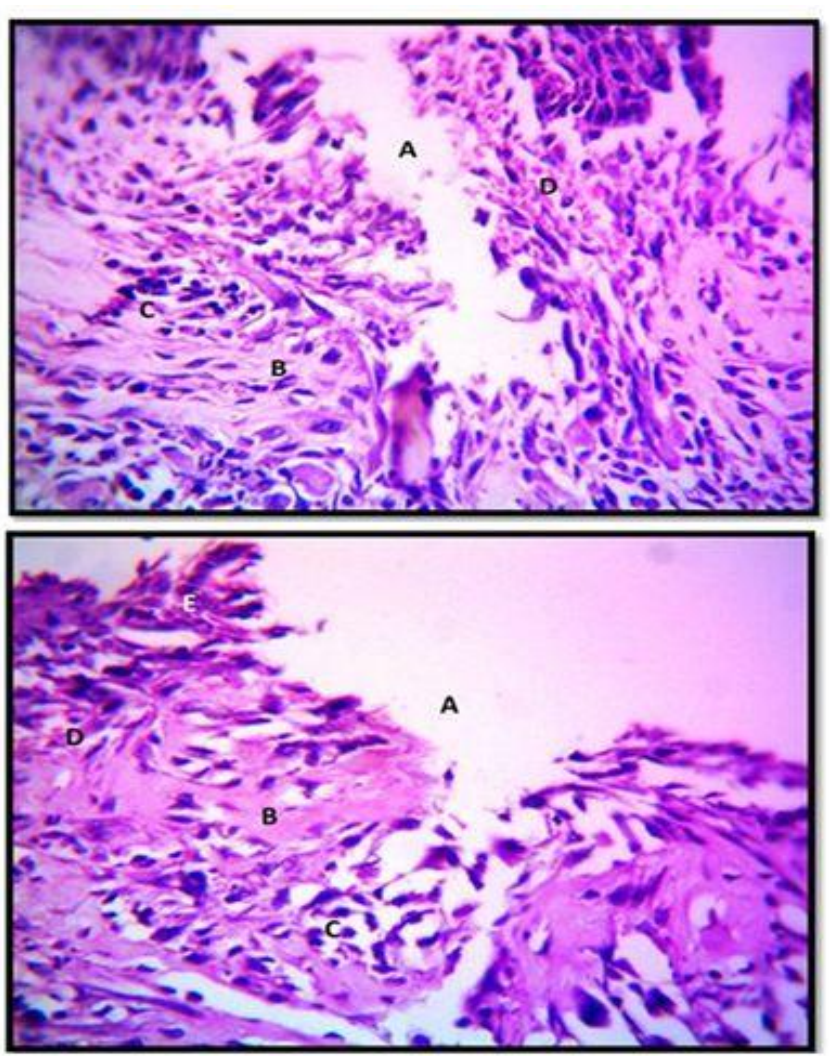

Fig. 4: Photomicrograph of the seven days oral mucosal wounds of I. Control group, II. Melatonin group (A) shows the site of the wound, (B) represents granulation tissue, (C) represents inflammatory infiltration, (D) show peripherally present newly blood vessels (angiogenesis), and (E) represents reepithelialization below half of the wound .H\&E stain, 400X for both sections.

Post-wounding at day ninth, the melatonin group remained the lowest in inflammatory cells infiltration and the highest in granulation tissue and reepithelialization wound healing score. The mean value of inflammatory cell infiltration $(2.8 \pm 0.44)$ of the control group and the mean value of granulation tissue (2.6 \pm 0.54)and reepithelialization $(1.4 \pm 0.54)$, while the mean value of inflammatory cell infiltrates $(1.6 \pm 0.89), \quad$ granulation tissue $(3.6 \pm 0.83)$ and reepithelialization $(3.2 \pm 0.83)$ of the group treated with melatonin that showed there was a significant difference in inflammation, granulation tissue formation, and reepithelialization (Figs. $5 \& 6$ ).

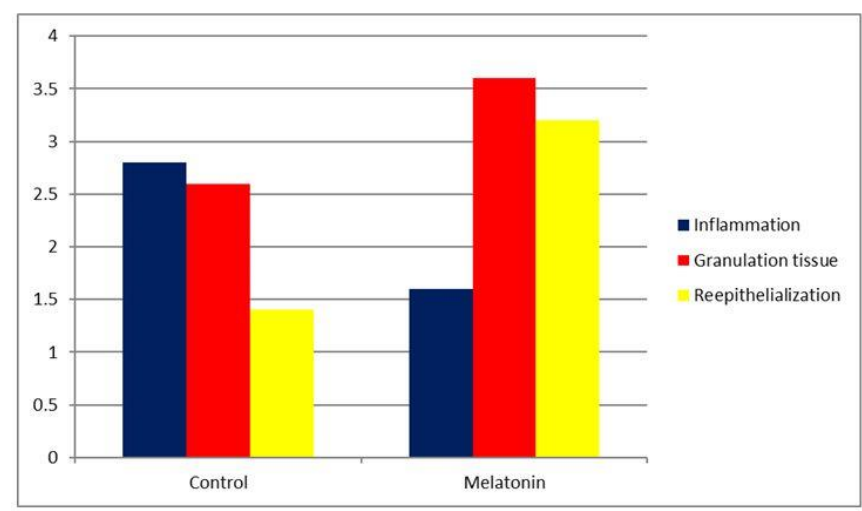

Fig.5: Mean rank differences between variables treated systemically on the 9th day of oral mucosa wound healing for inflammation, granulation tissue formation, and reepithelialization.

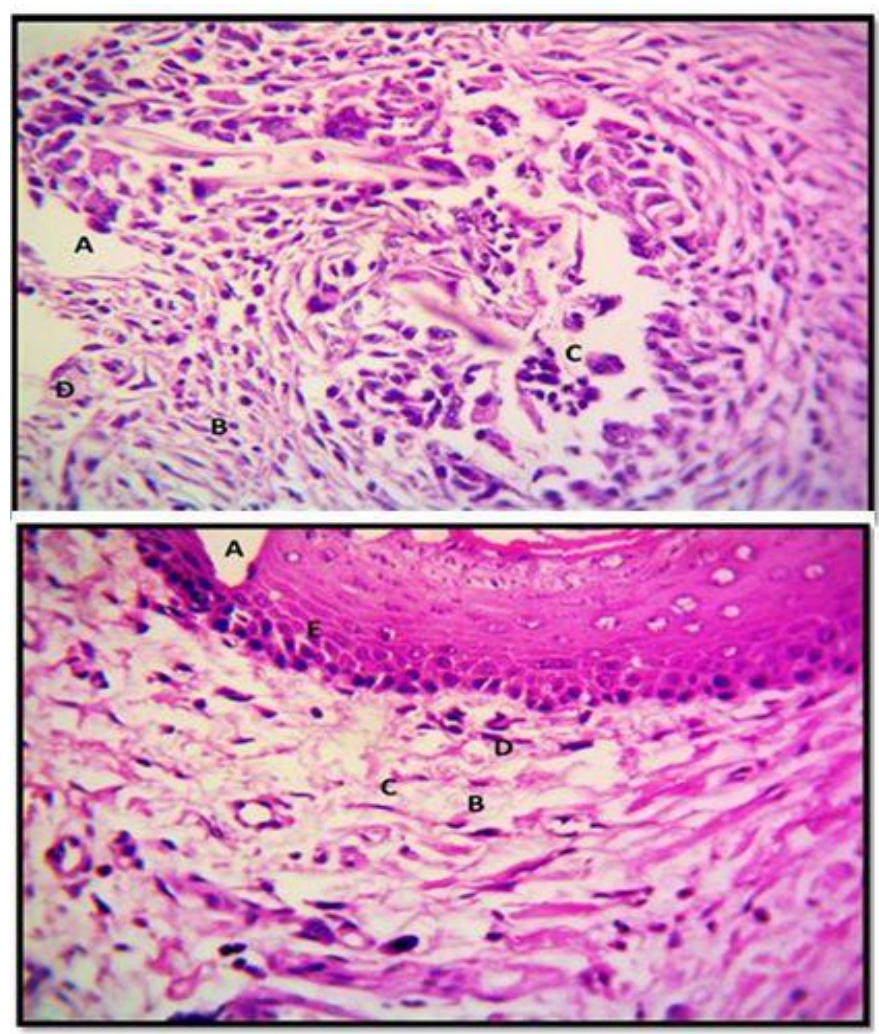

Fig. 6: Photomicrograph of nine-day period oral mucosal wound: I. Control group, II. melatonin. (A) shows the site of the wound, (B) representing granulation tissue, (C) representing inflammatory infiltration, (D) show peripherally present newly blood vessels (angiogenesis), and (E) representing reepithelialization below the half of the wound of the control group and also there is the irregular full thickness of reepithelialization at the site of the wound of melatonin group. H\&E stain, 400X for both sections. 


\section{Effects of Melatonin on Primary Oral Wound ......}

\section{DISCUSSION}

Wound healing is a complex process consisting of multi-steps that begins with the hemostasis and then inflammation and continue to granulate tissue formation, angiogenesis, reepithelialization, and wound contraction (Amirian et al., 2021). The first step in wound healing starts with the progression of the inflammatory reaction and the initial stage of the proliferation, with the granulation tissue progression (Broughton et al., 2006). this study showed that in contrast to the control group, the melatonin treated group reported a decrease in the inflammatory response and an increase in collagen deposition and this is an agreement with Soybir et al., (2003) that show melatonin has a positive effect on wound healing and also melatonin increases the angiogenesis which accelerates wound healing process.

The inflammatory phase is responsible for extensive response to microbial infection and removing the cellular debris from tissue (Politis et al., 2016; $\mathbf{L i}$ et al., 2021). It's also liable for the production of oxygen-free radicals. Tissue growth factors trigger the proliferative phase of the healing procedure and the new connective tissue matrix (Lin et al., 2012). Furthermore, persistent inflammation can cause wound healing to be delayed, leading to irregular wound repair or tissue fibrosis (Smith and Martínez 2018). The current study's histopathological finding significant difference in wound healing process between the control group and melatonin-treated groups, this action may be due to anti-inflammatory and antioxidant effect of melatonin (Nabavi et al., 2019), melatonin interacts with Tumor necrosis factor(TNF), Interleukin-2 (IL-2), and interleukin-4 (IL-4).

Many studies have demonstrated that the level of TNF is significantly lower in high melatonin levels, thus indicating a feedback mechanism between the pineal gland and TNF released from macrophages (Soybİr et al., 2003). Besides that, many studies show that melatonin significantly suppressed the proinflammatory factors IL- $1 \beta$ and TNF- $\alpha$ and reduced the relative gene expression of IL- $1 \beta, \mathrm{TNF}-\alpha$, and iNOS, so melatonin significantly promoted the healing of diabetic wounds by inhibiting inflammation, thereby further facilitating angiogenesis and collagen synthesis in vivo (Liu et al., 2020).

Also, the histopathological findings of the present research showed an acceleration in the healing of the wound in the treated group with melatonin and this is in agreement with Pugazhenthi et al., 2008 that shows melatonin treatment significantly improved the quality of scarring, both in terms of maturity and orientation of collagen fibers.
Evidence shows that many factors can cause cellular damage such as tissue neutrophil accumulation, the formation of the high level of reactive oxygen species (ROS) while undergoing reperfusion and high levels of calcium, and the activation of a high level of epithelial apoptosis are all important factors in the etiology of different forms of ischemia reperfusion injury in organ dysfunction and tissue damage (Chen et al., 2018), Melatonin treatment significantly decreased inducible Nitric oxide synthases (iNOS) activity during the acute inflammatory phase but significantly increased iNOS activity during the resolving phase (Pugazhenthi, et al., 2008).

Many studies show that melatonin has a powerful antioxidant effect, melatonin can scavenge the free radicals and also melatonin increases the levels of the antioxidant enzyme such as catalase (CAT), glutathione peroxidase (GSH-px), and Superoxide dismutase (SOD) also melatonin treatment decrease the level of Malondialdehyde (MAD) (Başak et al., 2003). Furthermore melatonin plays an important role as a potent radical scavenger of reactive oxygen species (ROS) and reactive nitrogen species (RNS). Its antioxidant properties are reported to be even more effective than vitamins C and E (Pieri et al.,1994).

In this research, there was an acceleration in the wound healing process and this is an agreement with Ozler $\boldsymbol{e t}$ al., 2010 that shown wound healing was prolonged in experimental animals deprived of melatonin through pinealectomy, so melatonin exerts positive effects on wound healing, whether it is administered topically or systemically (Ozler et al., 2010). Furthermore, the previous study shows that melatonin has antimicrobial activity, accelerating wound healing of burns and other skin lesions (Soriano et al., 2020).

\section{CONCLUSION}

The data of this study revealed that melatonin has anti-inflammatory effects and melatonin increases granulation tissue formation, so melatonin accelerates wound-healing of the primary oral mucosal wound.

\section{Declaration of Conflicting Interests}

The authors revealed that there is no potential conflicts of interest.

\section{REFERENCES}

ALMADANI, Y. H., VORSTENBOSCH, J., DAVISON, P., and MURPHY, A., 2021. Wound Healing: A Comprehensive Review. In Seminars in Plastic Surgery. Thieme Medical Publishers, Inc. DOI: 10.1055/s-0041-1731791

AL-SAFFAR, M. T., MAHMOOD, A. S., and SULAIMAN, M. S., 2020. Impact of Local Anesthesia on Wound Healing. Indian Journal of Forensic 
Medicine \& Toxicology; 14(4).EBSCOhost__ 148409434 Impact of Local Anesthesia on Wound Healing. files

AMIRIAN, J., ZENG, Y., SHEKH, M.I., SHARMA, G., STADLER, F.J., SONG, J., DU, B., and ZHU, Y., 2021. In-situ crosslinked hydrogel based on amidated pectin/oxidized chitosan as potential wound dressing for skin repairing. Carbohydrate Polymers, 251, p.117005.https://doi.org/10.1016/j.carbpol.2020.117005.

ANADÓN, A., ARES, I., MARTÍNEZ-LARRÃ̃AGA, M. R., and MARTÍNEZ, M. A., 2021. Melatonin: a safe nutraceutical and clinical agent. In Nutraceuticals (pp. 537-553). Academic Press. https://doi.org/10.1016/B978-0-12-821038-3.00034-3.

BAHADUR, S. 2021. Oral Cavity: Surgical Anatomy and Tumour Spread. In Management of Oral Cancers (pp. 69-81). Springer, Singapore. DOI: 10.1007/978-98115-6499-4_6.

BAŞAK, P. Y., AĞALAR, F., GÜLTEKIN, F., EROĞLU, E., ALTUNTAŞ, I., and AĞALAR, C., 2003. The effect of thermal injury and melatonin on incisional wound healing. Ulusal travma ve acil cerrahi dergisi= Turkish journal of trauma \& emergency surgery: TJTES, 9(2), 96-101. doi:10.1016/j.bja.2021.07.028.

CANCIANI, ELENA, RICCARDO SIRELLO, GAIA PELLEGRINI, DOLAJI HENIN, MARIACHIARA PERROTTA, MARILISA TOMA, NATALIYA KHOMCHYNA, and CLAUDIA DELLAVIA, 2021. "Effects of Vitamin and Amino Acid-Enriched Hyaluronic Acid Gel on the Healing of Oral Mucosa: In Vivo and In Vitro Study." Medicina 57(3):285. https://doi.org/10.3390/medicina57030285.

CHEN, GANG, HUGANG SHEN, LINLIN ZANG, ZHONGLAN SU, JILONG HUANG, YONG SUN, and HONGWEI WANG, 2018. "Protective Effect of Luteolin on Skin Ischemia-Reperfusion Injury through an AKT-Dependent Mechanism.” International Journal of Molecular Medicine 42(6):3073-82. https://doi.org/10.3892/ijmm.2018.3915.

DOS SANTOS, B. C. C., GOMES, J. C., MIOLA, A. E. Z., ROTHEN, S. K., RODRIGUES, C. P. M., COSTA, R. M., and NASSAR, C. A., 2020. Evaluation of the Effect of Melatonin on Periodontal Tissues in Rats with Periodontitis Induced Experimentally. Journal of Advances in Medicine and Medical Research, 115-126.

https://doi.org/10.9734/jammr/2020/v32i730457

GARCÍA-BERNAL, D., LÓPEZ-GARCÍA, S., SANZ, J. L., GUERRERO-GIRONÉS, J., GARCÍANAVARRO, E. M., MORALEDA, J. M., and RODRÍGUEZ-LOZANO, F. J., 2021. Melatonin Treatment Alters Biological and Immunomodulatory Properties of Human Dental Pulp Mesenchymal Stem Cells via Augmented Transforming Growth Factor Beta Secretion. Journal of Endodontics, 47(3), 424-435. https://doi.org/10.1016/j.joen.2020.12.008

GEORGE BROUGHTON, I. I., JANIS, J. E., and ATTINGER, C. E., 2006. The basic science of wound healing. Plastic and reconstructive surgery, $117(7 \mathrm{~S})$, 12S-34S doi: 10.1097/01.prs.0000225430.42531.c2.

GUPTA, A., and KUMAR, P., 2015. Assessment of the histological state of the healing wound. Plastic and Aesthetic Research, 2, 239-242. Dio:10.4103/23479264.158862
GURUNATHAN, S., QASIM, M., KANG, M. H., and KIM, J. H., 2021. Role and therapeutic potential of melatonin in various types of cancers. OncoTargets and therapy, 14, 2019.

https://www.ncbi.nlm.nih.gov/pmc/articles/PMC7987311/cite dby/\#.

HENG, K., MARX, J. O., JAMPACHAIRSI, K., HUSS, M. K., and PACHARINSAK, C., 2020. Continuous Rate Infusion of Alfaxalone during Ketamine-Xylazine Anesthesia in Rats. Journal of the American Association for Laboratory Animal Science, 59(2), 170-175. DOI: https://doi.org/10.30802/AALASJAALAS19000122.https://doi.org/10.1177/107424841666062 2. https://doi.org/10.3389/phys.2016.00507.

KUJATH, P., and MICHELSEN, A., 2008. WoundsFrom physiology to wound dressing. Deutsches Ärzteblatt International, 105(13), 239. doi: 10.3238/arztebl.2008.0239.

LERNER, A. B., CASE, J. D., TAKAHASHI, Y., LEE, T. H., and MORI, W., 1958. Isolation of melatonin, the pineal gland factor that lightens melanocyteS1. Journal of the American Chemical Society, 80(10), 2587-2587. https://doi.org/10.1021/ja01543a060.

LI, DONGQING, HONGMEI PENG, LE QU, PEHR SOMMAR, AOXUE WANG, TONGBIN CHU, XI LI, XINLING BI, QUEPING LIU, and IRÈNE GALLAIS SÉRÉZAL, 2021. "MiR-19a/b and MiR20a Promote Wound Healing by Regulating the Inflammatory Response of Keratinocytes." Journal of Investigative Dermatology 141(3):659-71 https://doi.org/10.1016/j.jid.2020.06.037.

LIN, TEOH SEONG, AZIAN ABD LATIFF, NOOR AINI ABD HAMID, and MUSALMAH MAZLAN, 2012. "Evaluation of Topical Tocopherol Cream on Cutaneous Wound Healing in Streptozotocin-Induced Diabetic Rats." Evidence-Based Complementary and Alternative Medicine 2012. https://doi.org/10.1155/2012/491027.

LIU, J., BIAN, Z., KUIJPERS-JAGTMAN, A. M., and VON DEN HOFF, J. W., 2010. Skin and oral mucosa equivalents: construction and performance. Orthodontics \& craniofacial research, 13(1), 11-20. https://doi.org/10.1111/j.1601-6343.2009.01475.x.

LIU, W., YU, M., XIE, D., WANG, L., YE, C., ZHU, Q., LIU, F., and YANG, L., 2020. Melatonin-stimulated MSC-derived exosomes improve diabetic wound healing through regulating macrophage M1 and M2 polarization by targeting the PTEN/AKT pathway. Stem cell research \& therapy, 11(1), pp.1-15..doi.org/ 10.1186/s13287-020-01756-X.

MARTIN, P., and NUNAN, R., 2015. Cellular and molecular mechanisms of repair in acute and chronic wound healing. British Journal of Dermatology, 173(2), 370-378. https://doi.org/10.1111/bjd.13954.

NABAVI, S.M., NABAVI, S.F., SUREDA, A., XIAO, J., DEHPOUR, A.R., SHIROOIE, S., SILVA, A.S., BALDI, A., KHAN, H., and DAGLIA, M., 2019. Anti-inflammatory effects of Melatonin: A mechanistic review. Critical reviews in food science and nutrition, 59(sup1), pp.S4-S16. https://doi.org/10.1080/10408398.2018.1487927.

NAJAFI, M., SALEHI, E., FARHOOD, B., NASHTAEI, M.S., HASHEMI GORADEL, N., 


\section{Effects of Melatonin on Primary Oral Wound ......}

KHANLARKHANI, N., NAMJOO, Z., and MORTEZAEE, K., 2019. Adjuvant chemotherapy with melatonin for targeting human cancers: A review. Journal of cellular physiology, 234(3), pp.2356-2372.. https://doi.org/10.1002/jcp.27259.

NAJEEB, S., KHURSHID, Z., ZOHAIB, S., and ZAFAR, M. S., 2016. Therapeutic potential of melatonin in oral medicine and periodontology. The Kaohsiung journal of medical sciences; 32(8): 391-396. https://doi.org/10.1016/j.kjms.2016.06.005.

OZLER, M., KORKMAZ, A., UYSAL, B., SIMSEK, K., OZKAN, C., TOPAL, T., and OTER, S., 2011. Effects of topical melatonin and vitamin $\mathrm{E}$ in a rat ischemic wound model. J Exp Integr Med, 1, 123.DOI:10.5455/jeim.080411.or.006.

OZLER, M., SIMSEK, K., OZKAN, C., AKGUL, E. O., TOPAL, T., OTER, S., and KORKMAZ, A., 2010. Comparison of the effect of topical and systemic melatonin administration on delayed wound healing in rats that underwent pinealectomy. Scandinavian journal of clinical and laboratory investigation, 70(6), 447-452. https://doi.org/10.3109/00365513.2010.506926.

PANDI-PERUMAL, S.R., BAHAMMAM, A.S., OJIKE, N.I., AKINSEYE, O.A., KENDZERSKA, T., BUTTOO, K., DHANDAPANY, P.S., BROWN, G.M., and CARDINALI, D.P., 2017. Melatonin and human cardiovascular disease. Journal of cardiovascular pharmacology and therapeutics, 22(2), pp.122-132.

PIERI, C., MARRA, M., MORONI, F., RECCHIONI, R., and MARCHESELLI, F., 1994. Melatonin: a peroxyl radical scavenger more effective than vitamin E. Life sciences, 55(15), PL271-PL276. https://doi.org/10.1016/0024-3205(94)00666-0.

PRASETYONO, T. O. 2009. General concept of wound healing, revisited. Medical Journal of Indonesia, 18(3), 208-16. https://doi.org/10.13181/mji.v18i3.364.

POLITIS, CONSTANTINUS, JOSEPH SCHOENAERS, REINHILDE JACOBS, and JIMOH O. AGBAJE, 2016. "Wound Healing Problems in the Mouth." 7(November):1-13. https://doi.org/10.3389/fphys.2016.00507

PUGAZHENTHI, K., KAPOOR, M., CLARKSON, A. N., HALL, I., and APPLETON, I., 2008. Melatonin accelerates the process of wound repair in full-thickness incisional wounds. Journal of pineal research, 44(4), 387-396. https://doi.org/10.1111/j.1600-079X.2007.00541.X.

SALLEH, A., and FAUZI, M. B., 2021. The In Vivo, In Vitro and In Ovo Evaluation of Quantum Dots in Wound Healing: A Review. Polymers, 13(2), 191. https://doi.org/10.3390/polym13020191.

SMITH, PATRICIO C., AND CONSTANZA MARTÍNEZ. 2018. "Wound Healing in the Oral Mucosa." DOI: 10.1007/978-3-319-56065-6_6.

SORIANO, J. L., CALPENA, A. C., RINCÓN, M., PÉREZ, N., HALBAUT, L., RODRÍGUEZLAGUNAS, M. J., and CLARES, B., 2020. Melatonin nanogel promotes skin healing response in burn wounds of rats. Nanomedicine, 15(22), 21332147. doi/full/10.2217/nnm-2020-0193.

SOYBİR, G., TOPUZLU, C., ODABAŞ, Ö., DOLAY, K., BİLİ, A., and KÖKSOY, F., 2003. The effects of melatonin on angiogenesis and wound healing. Surgery today, 33(12), 896-901. doi.org/10.1007/s00595-0032621-3.

SULTANA, JACHMEN, MOTIUR RAHMAN MOLLA, MOHAMMED KAMAL, M. SHAHIDULLAH, FERDOUSY BEGUM, and ABUL BASHAR, M.D., 2009. "Histological Differences in Wound Healing in Maxillofacial Region in Patients with or without Risk Factors." Bangladesh Journal of Pathology 24(1):3-8. https://doi.org/10.3329/bjpath.v24i1.2874.

TANG, J., HAN, Y., ZHANG, F., G.E., Z., LIU, X., and L.U., Q., 2015. Buccal mucosa repair with electrospun silk fibroin matrix in a rat model. The International Journal of artificial organs, 38(2), 105-112. https://doi.org/10.5301/ijao.5000392.

TAŞ, A., KARASU, A., YENER, Z., YILDIRIM, S., ATASOY, N., DÜZ, E., and YAVUZ, E., 2015. Histopathological and Immunohistochemical Study of the Effect of Sildenafil Citrate, Vitamin A, Vitamin C and Vitamin E on Wound Healing in Alloxan-Induced Diabetic Rats. https:// DOI: 10.7727/wimj.2015.596

How to cite this article:

Saja M. Mohammed, Mohammed S. Sulaiman and Ghada A. Taqa, 2022. Effects of Melatonin on Primary Oral Wound Healing in Rats. Journal of Applied Veterinary Sciences, 7 (1): $24-30$.

DOI:https://dx.doi.org/10.21608/javs.2021.98771.1108 